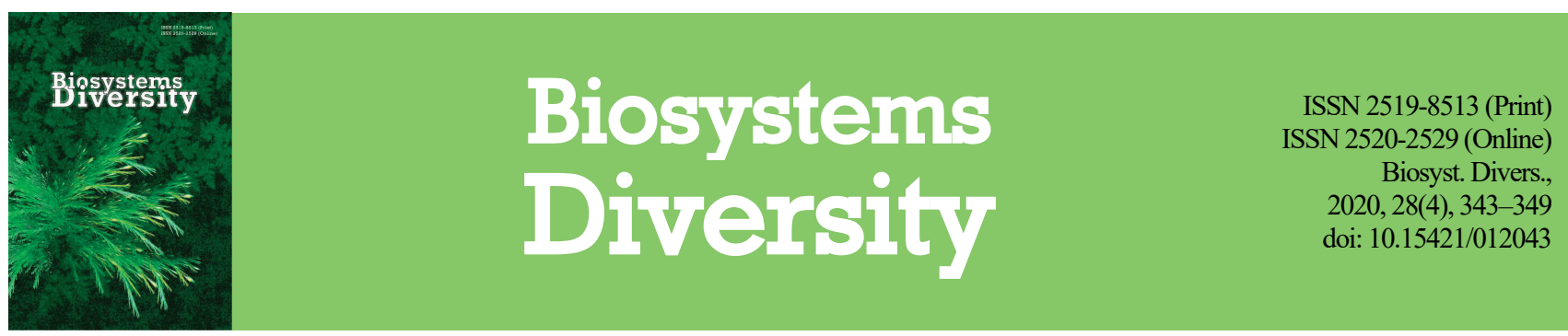

\title{
Distribution of adventive species Solidago canadensis, Phalacroloma annuum, Ambrosia artemisiifolia, Heracleum sosnowskyi in phytocenoses of Volyn' Polissya (Ukraine)
}

\author{
L. V. Oitsius*, H. P. Volovyk*, S. P. Doletskyi**, A. V. Lysytsya* \\ *Rivne State University of Humanities, Rivne, Ukraine \\ **National Academy of Agrarian Sciences of Ukraine, Kyiv, Ukraine
}

Article info

Received 18.10.2020

Received in revised form

14.11.2020

Accepted 15.11 .2020

Oitsius, L. V., Volovyk, H. P., Doletskyi, S. P., \& Lysytsya, A. V. (2020). Distribution of adventive species Solidago canadensis, Phalacroloma annuum, Ambrosia artemisiifolia, Heracleum sosnowskyi in phytocenoses of Volyn' Polissya (Ukraine). Biosystems Diversity, 28(4), 343-349. doi:10.15421/012043

Rivne State University of Humanities,

Stepana Bandery st., 12 ,

Rivne, 33028, Ukraine.

Tel.: +38-097-332-24-66.

E-mail: lysycya@ukr.net

National Academy

of Agrarian Sciences

of Ulvaine, Mykhayla

Omelianovycha-Pavlenka st.

9, Kyiv, 01010, Ukraine.

Tel.: +38-044-521-92-86

E-mail:vetuaan@meta.ua

Biological pollution of natural phytocenoses by adventive plant species poses is a serious threat to endemic species and species with narrower ecological amplitude in ecosystems around the world. This study presents the results of a study of the composition and distribution of adventive plant species in natural, semi-natural and anthropogenic transformed phytocenoses of Volyn' Polissya, Ukraine. To clarify the effect of drainage melioration on non-native flora species distribution, a botanical study was carried out during the 2003-2019 vegetation seasons on the territory of four drainage systems. The adventive flora of this unique region of Europe was studied in detail for the first time. In total, 279 non-native plant species were found. They belong to 110 genera and 32 families. The results of studying the systematic, bioecological, range-distributional and phytogenetic structure of adventive species found within agricultural lands and adjacent territories are presented. It was found that 161 species are associated with agricultural production. Of these, 90 species were found directly within the agricultural land, another 71 species were found growing in the adjacent territories. It was found that a significant increase in the number of adventive species on the territory of Volyn' Polissya is associated with drainage melioration carried out in the 1960-1990s, significant changes in the structure and forms of agro-industrial production, and climatic changes in recent decades. The expansion of agricultural land in this area over the past 50-60 years has led to an increase in the number of adventive species by more than $60 \%$. On the territory of drainage systems used for agricultural activities, more than $40 \%$ of the total species composition of the adventive flora of Volyn' Polissya is represented. The majority of these species originate from arid and sub arid regions of the planet. The transformer plants, Solidago canadensis L. and Phalacroloma annuum (L.) Dumort pose a potential threat to phytocenoses of the described region, as well as the whole of Europe. Of particular interest are the species that in the future may pose a serious threat to natural phyto-diversity and have negative practical consequences for the structure of agricultural landscapes. These are Ambrosia artemisiifolia L. and Heracleum sosnowskyi Manden. In general, modern agro ecosystems are characterized by instability and low ability to resist non-native species. The strongly weedy character of cultivated fields and the presence of abandoned uncultivated lands have caused the rapid spread of adventive vegetation. In order to further optimize the structure of agrolandscapes, it is advisable to monitor and regulate not only expansionary invasive species, which is especially important for preventing biological pollution, but also species whose status has not yet been determined.

Keywords: plant invasions; adventive plants; drainage melioration; anthropogenic transformation of phytocenoses.

\section{Introduction}

The penetration and consolidation of invasive plant species leads to the unification of the flora of various regions of the world. This causes the loss of specific regional features due to the displacement of local, first of all, stenotopic plant species by adventive species and poses an immediate danger to the existence of endemic species and species with narrower ecological amplitude. The process of fixation of introduced species of flora in new territories is facilitated by the total destruction of habitats of autochthonous species typical for the regions and an increase in the areas occupied by anthropogenic transformed landscapes. Globally, adventization leads to the "homogenization" of natural ecosystems and the biosphere as a whole.

Nowadays botanists are seriously concerned about the sharp increase in the proportion of adventive species in the composition of regional floras. Alien plant species are found in the flora of all natural regions of the world, with the exception of Antarctica. The average share of such species in regional floras is estimated at $5-15 \%$, while on the continents it is $11 \%$, and on islands up to $31 \%$. The maximum proportion of adventive species (up to $50 \%$ ) is noted within agricultural and urban ecosystems; they are followed by forests of the temperate zone, in the flora of which the proportion of adventive species reaches $22 \%$. For example, by the end of the last century, invasive plant species in the biome of Mediterranean sclerophytic shrubs accounted for 17\% (Jager, 1988; Lonsdale, 1999), and in the weedfield flora of North America, the number of adventive species reached 60\% (Baker, 1986).

Volyn' Polissya of Ukraine is a complex of biocenoses, unique both for Europe and for the whole world. A noticeable expansion over the past 50 years of the scale of agricultural production on the territory of Volyn' Polissya has largely influenced its natural complexes and flora, as their integral component. Growing of cultivated plants on large areas that were previously occupied by natural phytocenoses, and the use of grasslands for grazing animals or haymaking cause significant negative changes in the species composition of the spontaneous flora of the region.

The region is characterized by a flat relief, a temperate climate, a zone of mixed forests, and a large number of wetlands. The tectonic and geological structure determines a significant variety of agrosoil conditions. On the territory of Polissya, acidic soils with low humus content prevail: turf-gleyed, turf-hidden-podzolized sandy (brown sands), low-lying and peat-boggy peatlands, in the lowlands of rivers there are meadow and 
meadow-chernozem soils (Korotun \& Korotun, 1996; Dolzhenchuk \& Krupko, 2015). Over the past 30 years, the average annual air temperature has increased by $1.0-1.5^{\circ} \mathrm{C}$. The sums of active temperatures increase, the amount of precipitation decreases, and the conditions for atmospheric humidification deteriorate. At the same time, there is an increase in conditions and phenomena dangerous for agriculture: the frequency of occurrence of atmospheric drought, the number of days with dry wind, the number of days with frost, the duration of the frost-free period and the frequency of years with freezing of winter crops. Proceeding from economic feasibility and climatic possibilities for the period after 1991 there have been changes in the structure of cultivated areas. The range of cultivated crops has expanded, namely, significant areas of industrial crops corn, rapeseed, sunflower and soybeans have appeared. The production of grain and leguminous crops has decreased by 2 times; sugar beet by 140 times, the cultivation of flax has completely stopped. Potato production has increased by $80 \%$ and vegetable production by $130 \%$. The main trends of the last three decades: an increase in the sown area of industrial crops, which, in turn, displace traditional crops, attempts to intensify farming, a decrease in the amount of mineral fertilizers applied by 2.0 times, organic fertilizers by 15.0 times, a decrease in the number of cattle by 6.0 times, pigs by 2.2 times, sheep and goats by 9.3 times. All this increases the imbalance of the agroecosystems of the region, as a result of which their self-reproduction and self-regulation is disrupted (Sobko \& Voznyuk, 2018).

Due to the lack of clear forecasting and sufficient information on the contamination of crops and soil, the protection of crops from weeds is carried out without taking into account the zone characteristics of growing crops, while the farms lose on average up to $15-20 \%$ of plant production (Kochik, 2012).

A very noticeable role in the spread of adventive (from Latin adventicius - alien) plant species in the Polissya region was played by the largescale drainage melioration carried out in the 1960-1980s, due to which the areas of land suitable for use in agricultural production were significantly expanded. The negative role of drainage in this case was manifested in the disturbance of the soil cover during the laying of the irrigation and drainage network and in the general decrease in the water content of the territory - not only directly drained, but also adjacent areas. Since non-native plant species are predominantly from sub-arid and arid regions, a significant decrease in the level of groundwater and an increase in the average annual temperature have become positive factors for them.

It should be noted that the spread of adventive, or non-native, plant species has now acquired a global character and encompassed both Europe and all other continents of the planet (Hadjikyriakou \& Hadjisterkotis, 2002; Ward \& Amatangelo, 2018; Witt et al., 2018; Sabirova et al., 2019). It has become one of the manifestations of biological pollution of the territory and is one of the main factors in the transformation of autochthonous floras in different regions. Indigenous plant species are being forced out by invasive ones due to the adventitization of regional natural floras. This leads to the loss of specificity of phytocenoses and their unification. This poses an immediate threat to the conservation of biodiversity (Baležentienè et al., 2013; Yakubenko \& Churilov, 2019).

The problem of adventization of indigenous flora is quite acute for Ukraine as well. Adventive species make up about $14 \%$ of the total number of flora species in the country. This process is progressing: the rates of introduction, distribution and the degree of naturalization of species are growing. In the flora of Ukraine, there are no longer any flora complexes in which adventive plant species are absent (Protopopova et al., 2003). Invasive adventive plants take root even in arboreal and shrub cenoses, which usually have the most stable structure (Richardson, 2000; Kauffer et al., 2013; Burda, 2015, 2018; Khomyak, 2018).

Based on the current situation, the priority directions of the national concept on the problem of non-native species were developed and substantiated. They provide for the creation of a scientific base through a complete inventory of the adventive fraction of the flora of Ukraine, and mapping of locations, and determination of the status of various groups of invasive species (Protopopova et al., 2003).

Due to the relatively low degree of development of the Ukrainian Polissya in the past, botanists paid little attention to the study of alien plant species on its territory. The interest in such research increased after large- scale drainage reclamation and reclamation of land for agricultural use in the 1960-1980s (Blinkova, 2017). After the first stage of reclamation, 132 weed species were described in the drained areas (Artemenko \& Beskrovny, 1972). Later, in one of the most complete surveys of the synanthropic flora of Ukraine, it was noted that one of the main reasons for the spread of synanthropic species on the territory of Polissya was the drainage and further development of drained lands (Protopopova, 1991). We studied the adventive flora throughout the region (Volodymyrets \& Shklyaruk, 2006). However, in all these studies, the problem of the influence of agriculture on the spread of invasive plant species was left without attention of the authors.

The increase in the number of non-native plant species in the flora of Volyn' Polissya, despite the influence of other factors, is largely associated with the intensification of agriculture. Nowadays, adventive species belonging to agroecosystems have not been singled out separately, and no assessment has been made of the level of their invasive threat. Over the past decade, the composition of adventive plants in agricultural landscapes has been replenished. The task arose of analyzing the species diversity of adventive plants and assessing their ecological threat. Therefore, the purpose of our research is to analyze the species composition of adventive plant species in the agricultural landscapes of Volyn' Polissya and to determine the relationship between their distribution and the characteristics of agriculture.

\section{Materials and methods}

To determine the effect of drainage reclamation on the distribution of non-native species of flora, studies were carried out on the territory of four drainage systems located within Volyn' Polissya and adjacent territories. The main routes during the growing season were: the drainage system Tsyrs'ka (Kamin'-Kashyrs'ky district of the Volyn' region), DerazhnePostiyne and Pechalivs'ka (Kostopols'ky district of the Rivne region), Vorobyne (Dubrovyts'ky district of the Rivne region). The duration of monitoring and annual botanical research of the flora of various regions on the territory of Volyn' Polissya was 16 years (2003-2019).

We also used the results of our other studies (Oitsius, 2014) and herbarium materials from the funds of the Rivne Regional Museum of Local Lore, the Department of Agrochemistry, Soil Science and Agriculture of the National University of Water and Environmental Engineering (Rivne), the Department of Microbiology and Botany of the Eastern European University (Lutsk).

The designation of adventive plant species and their characteristics were carried out according to the conspectus of the synanthropic flora of Ukraine (Protopopova, 1991; Protopopova \& Shevera, 2012) and the annotated list of adventive plant species (Protopopova et al., 2003). Plant life forms were designated according to the ecological classification (Raunkiaer, 1934; Serebryakov, 1962). The phytocenotic role of adventive plant species was determined on the basis of descriptions of sample plots, $5 \times 5 \mathrm{~m}$ in size, in accordance with the generally accepted methodology (Rabotnov, 1983). Plots under different types of economic use and different intensity of anthropogenic load were selected for descriptions.

We have classified adventive species by time of settlement according to Kornas (1968), Protopopova \& Shevera (2012).

\section{Results}

On the territory of Volyn' Polissya, we found 279 species of adventives plants belonging to 32 families. 161 species of which, or $57.8 \%$, are associated with agricultural production. At the same time, 90 species were found directly within the agricultural land, another 71 species were found growing in the adjacent areas. At the same time, the most numerous were 5 families, which include 97 species, or $60.2 \%$ of the total number of recorded species (Fig. 1).

Families such as Lamiaceae, Solanaceae, Boraginaceae, Apiaceae include 5 or more species. The rest are represented by several species, and 12 families, or about $38 \%$ of their total number, were represented by only one species. It should be noted that a significant number of families with one or several species are a characteristic feature of adventive floras in general. Concerning plant genera, Chenopodium, Vicia, Lamium were 
distinguished by the greatest number of species. Most of the other genera were represented by a small number of species or only one species.

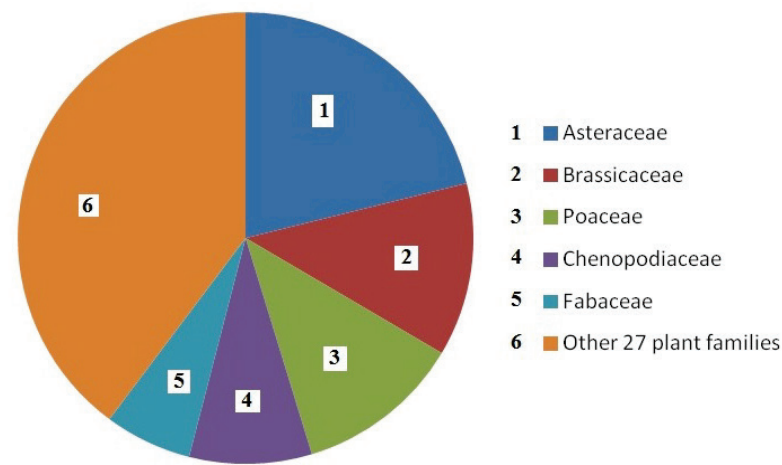

Fig. 1. Shares of the identified 32 families of adventive plant species, the main 5 families are: Asteraceae (34 species / 21.1\%), Brassicaceae (20 species / 12.4\%), Poaceae (19 species / 11.8\%), Chenopodiaceae

(14 species / 8.7\%), Fabaceae (10 species / 6.2\%): in the territory of Volyn' Polissya the monitoring period (2003-2019)

The dominating majority of invasive plant species that are associated with the agrarian sphere are widespread and are found more or less usually or scattered practically throughout the Volyn' Polissya region. These include some of the species that are recognized in Ukraine as being in a state of expansion: Lepidotheca suaveolens (Pursh) Nutt., Galinsoga parviflora Cav., Iva xanthiifolia Nutt., Phalacroloma annuum (L.) Dumort, Geranium sibiricum L., Helianthus tuberosus L., H. subcanescens (A. Gray) E. E. Wats., Heracleum mantegazzianum Sommier et Levier, H. sosnowskyi Manden. And also species that have a high potential for invasion: Capsella bursa-pastoris (L.) Medik., Echinochloa crusgalli (L.) Beauv., Papaver rhoeas L., Raphanus raphanistrum L., Setaria glauca (L.) Beauv., Sonchus oleraceus L., Tripleurospermum inodorum (L.) Sch., Amaranthus retroflexus L., Conyza canadensis (L.) Cronq.

According to the time of settlement of adventive species, the ratio of the number of archaeophytes (recorded in ancient times), kenophytes (found after the 15th century) and eukenophytes (recently introduced species) among the plant species noted by us is approximately the same (Table 1).

Table 1

Distribution of species of the adventive fraction of the flora according to the time of entry into the territory of Volyn' Polissya

\begin{tabular}{|c|c|c|}
\hline Groups of chrono elements & Number of species & $\%$ species \\
\hline Archeophytes & 73 & 45.3 \\
\hline Kenophytes & 74 & 46.0 \\
\hline Eukenophytes & 14 & 8.7 \\
\hline Total & 161 & 100.0 \\
\hline
\end{tabular}

To study the nature of the distribution of non-native species of flora in areas affected by drainage reclamation, floristic and phytocenotic studies were carried out on the territory of 4 separate drainage systems. About 40 adventive species were found. Taking into account the data obtained for other drainage systems in the region, the total number of invasive plant species is 68 . This is more than $40 \%$ of the total species composition of the adventive flora of Volyn' Polissya. The distribution of introduced species of flora on agricultural lands under various types of use for individual drainage systems is shown in Table 2 . The largest number of invasive species is concentrated on arable land with row crops, broadcast sowing crops and adjacent areas. A slightly smaller number of non-native species was found in the composition of crops of perennial grasses and meadows used mainly for intensive grazing. The smallest number of adventive plant species is presented in the areas used mainly as hayfields or for light grazing. This applies to both archaeophytes and kenophytes. It should be noted that, in contrast to other sites, the number of kenophytes in the territory of drainage systems is significantly lower than that of archaeophytes. However, kenophytes are predominantly entrenched in row crops and cultures of broadcast sowing. Most of the alien species are common and were present in almost all the studied sites. We found in the study area a significant distribution of two species of transformer plants
(Fig. 2), which alter the abiotic conditions of habitats and displace native species of flora. These are Solidago canadensis L. and Phalacroloma annuum (L.) Dumort.

Table 2

Distribution of non-native species of flora

on agricultural lands of drainage systems of Volyn' Polissya

\begin{tabular}{lccccc}
\hline \multirow{2}{*}{ Type of agricultural land } & \multicolumn{5}{c}{ Drainage systems } \\
\cline { 2 - 6 } & Tsyrs'ka & $\begin{array}{c}\text { Derazhne- } \\
\text { Postiyne }\end{array}$ & $\begin{array}{c}\text { Pecha- } \\
\text { livs'ka }\end{array}$ & $\begin{array}{c}\text { Voro- } \\
\text { byne }\end{array}$ & $\begin{array}{c}\text { overall } \\
\text { for systems }\end{array}$ \\
\hline Arable land, row crops & $11 / 5$ & $10 / 3$ & $11 / 3$ & $10 / 3$ & $12 / 6$ \\
$\begin{array}{l}\text { Arable land, broadcast sowing } \\
\text { Arable land, perennial grasses } \\
\text { (for haymaking) }\end{array}$ & $12 / 5$ & $20 / 7$ & $11 / 3$ & $14 / 5$ & $20 / 8$ \\
$\begin{array}{l}\text { Arable land, perennial grasses } \\
\text { (for permanent grazing) }\end{array}$ & $9 / 2$ & $2 / 1$ & $6 / 2$ & $5 / 2$ & $7 / 3$ \\
$\begin{array}{l}\text { Meadowlands(forhaymaking) } \\
\text { Meadowlands(for permanent }\end{array}$ & $4 / 2$ & $4 / 3$ & $9 / 2$ & $7 / 2$ & $10 / 5$ \\
grazing) & $7 / 2$ & $4 / 2$ & $9 / 1$ & $5 / 2$ & $9 / 3$ \\
\hline \multicolumn{1}{c}{ Total non-native species } & $18 / 9$ & $21 / 8$ & $22 / 7$ & $17 / 5$ & $25 / 11$ \\
\hline
\end{tabular}

Note: the numerator denotes the number of archaeophytes, the denominator denotes kenophytes.

Solidago canadensis L., Canadian goldenrod, is an eukenophyte of North American origin, according to the method of introduction - ergaziophyte, it is commonly found throughout the territory of Volyn' Polissya, more often in the southern part. A rapid increase has been observed over the past 20 years in the number of localities of the species and an increase in the areas it occupies. Local thickets have a projective cover of up to $95 \%$ often. According to our observations, goldenrod prefers moderately moist, with a transition to dry, places of growth on mesotrophic soils, with sufficient illumination or slight shading. It rather quickly captures areas with disturbed herbaceous vegetation, completely rebuilding the structure of the biocenosis.

Phalacroloma annuum (L.) Dumort. is a one-year kenophyte of North American origin, it is xenophyte by the method of introduction and found commonly throughout the region. The species is an agro-epecophyte, growing in transformed and natural phytocenoses. It prefers moderately humid growing places with sufficient light or partially shaded. In natural phytocenoses, it attains its greatest extent of projective cover in meadows, and it often gives the impression of a completely indigenous species. Local thickets can form in sparse shrub groups, on forest edges, in forest clearings. It withstands trampling and mowing well, therefore it is present in significant quantities in pastures, especially in drained river floodplains, along unmetalled roads through fields and along highways.

Of the species that have naturalized, of particular interest are species that in the future may pose a serious threat to natural phytodiversity and have negative practical consequences for the agricultural landscapes of our region and other parts of Europe. These are Ambrosia artemisiifolia L. and Heracleum sosnowskyi Manden.

Ambrosia artemisiifolia L. - ragweed, it is eukenophyte of North American origin, according to the degree of naturalization - epecophyte, it is a weed of internal quarantine. In Volyn' Polissya, it is scattered throughout the territory. Populations of the species mainly have a linear spatial structure, mainly confined to transport routes. Rarely, ragweed is found near field roads and paths, sometimes in spontaneous dumps or on the outskirts of fields. Ragweed is found quite often along railway lines, where it forms monodominant ruderal groupings. The species prefers well-lit open areas; it grows often on poor sandy loam soils, where there is no competition from other species. It was not found in semi-natural and natural groups. Now it is found around all the cities of the Volyn' Polissya region, these are: Kovel', Sarny, Kostopil', Berezne, Dubrovyt'sya, Varash, Rozhyshche, Kamin'-Kashyrs'ky, Zarichne, Lyuboml', Yagodyn. In rural settlements, ragweed was found in the villages Derazhne, Sus'k (Kostopols'ky district), Nobel' (Zarichnian'ky district), near Lyubomyrs'k railway station (Rivne district). According to our observations, the number of populations of the species varies from year to year. This is probably due to weather conditions. There is currently no noticeable increase in the number of populations. The spread of the species is primarily promoted by non-observance of the proper phytosanitary rules near railways and highways, as well as in cities and other settlements. 


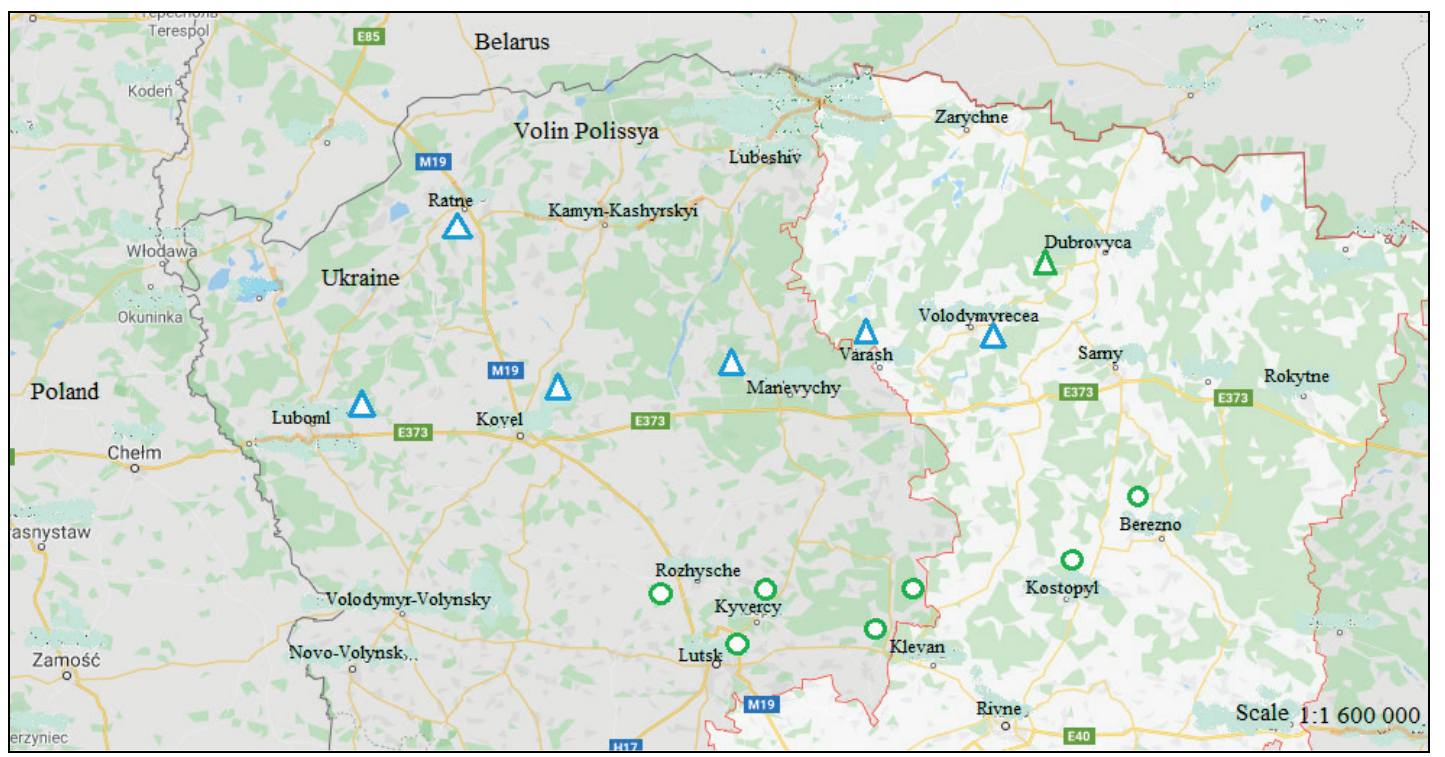

Fig. 2. The distribution of transformer plants on the territory of Volyn' Polissya:

- Solidago canadensis (L.) and $\Delta$ - Phalacroloma annuum (L.) Dumort.; results of annual monitoring for the period 2003-2019

Heracleum sosnowskyi Manden. - Sosnowsky's hogweed, it is a eukenophyte of Caucasian origin, ergaziophyte (by the method of introduction; it was brought into the region as a silage culture), agro-epecophyte. It poses a threat to natural and anthropogenically transformed territories throughout Eastern Europe. It is found mainly in the southern part of the territory of Volyn' Polissya. Today, this hogweed grows in the vicinity of the village of Orzhiv (Rivne region) and Derazhne, as well as to the northwest of it (drainage system Derazhne-Postiyne, Kostopols'ky district), village Klepachiv (Kivertsivs'ky district), town of Kovel', village Rechytsya (Goshchans'ky district). The largest population was found in the drainage system Derazhne-Postiyne in Kostopols'ky district. Here it occupies an area of about 0.4 hectares and forms monodominant groupings with projection cover of about $70 \%$. In other localities, this hogweed species is currently represented mainly by small groups, where there are about 10 15 individuals. The species prefers natural meadow phytocenoses with sufficient moisture and rich soils, most often found in river floodplains. Soznowsky's hogweed grows on the outskirts of Orzhiv village (Rivne region) near forest roads and in sparse thickets of bushes. The trend is towards an increase in the number of individuals of the species and an increase in population density in the identified localities over the past 20 years, according to our observations.

\section{Discussion}

The general floristic proportions of families, genera, and species of the adventive share of the flora of Volyn' Polissya growing on agricultural land are approximately $1.0: 3.4: 5.0$. This proportion indicates the low representation of the lower taxa among the higher ones. The ratio of the number of genera to the number of families is slightly higher, and the ratio of the number of species to the number of families is much lower than for the adventive flora of Ukraine as a whole (Protopopova \& Shevera, 2014). Analysis shows that the entry of adventive species of flora to new sites most often occurs together with seed or planting material. Significant danger is posed by insufficiently purified material brought from completely different or rather remote regions. In addition, the spread of invasive weed species occurs during the transportation of the productive part of plants, which often contains their seeds.

In some cases, feral cultivated plants become adventive species. Mitigation of climatic conditions contributes to this, in particular, warm winters. We have noted that crops such as Solanum tuberosum, Beta vulgaris, Allium sativum, Coriandrum sativum, Anethum graveolens, Papaver somniferum, Glycine max, Lupinus luteus, Cucurbita pepo have become wild in Volyn' Polissya in recent years.

The large number of archaeophytes is caused by the peculiarities of the natural conditions of the region and the ecological specificity of the drained territories. Such a chronological distribution of adventivesspecies indicates that the reclaimed territories are primarily represented by those species that have been introduced to the territory of Ukraine for a long time. However, the presence of kenophytes and a significant number of eukenophytes indicates the intensification of the processes of introduction of new species here.

The identified adventive species are diverse in origin. There is a numerical predominance of only a few groups. The most numerous is the group of species of Mediterranean origin. This accounts for about $60 \%$ of all invasive species. More than a quarter of the species composition comes from different regions of Asia. No more than $10 \%$ of alien species are of North American origin. Such a distribution of non-native species by origin clearly indicates the close connection of most of them with arid and subarid regions of the planet. Therefore, the gradual aridization of the Volyn' Polissya territory contributes to the successful naturalization of invasive species. According to the distribution range structure, among the alien plant species identified in agricultural lands and adjacent territories, the largest part is made up of Holarctic, cosmopolitan and hemi-cosmopolitan species, that is, species with a wide range. In total, they make up about two-thirds of the total.

Our research has shown that most adventive plant species are represented by five families: Asteraceae, Brassicaceae, Poaceae, Chenopodiaceae, and Fabaceae. This is generally consistent with the data of some other authors (Dubyna et al., 2019). By comparison, in the spectrum of families of adventive flora of the lowland forest regions of Ukraine, which includes the territory of Volyn' Polissya, the Brassicaceae family is in the first place, while Asteraceae is in second place. The families Poaceae and Fabaceae are also in third and fifth places, respectively. The Chenopodiaceae family takes only sixth place here (Burda, 2017). These differences in the spectrum of the main families indicate not only the ecological and geographical features of the region, but also the specifics of agricultural land. Annual herbaceous plants (about 70\%) and perennial herbaceous polycarpic plants (about 20\%) make up the largest part in the structure of life forms according to the ecological classification (Serebryakov, 1962) among all the non-native plant species recorded by us. Other life forms are scarce. The following plant life forms are most widely represented on agricultural lands: therophytes (annual plants that overwintered as seeds or spores), geophytes (species in which renewal buds are located on underground organs: bulbs, rhizomes, roots) and sometimes hemicryptophytes (herbaceous perennials, renewal buds which are laid close to the soil surface and for the winter are covered with a dead aerial part). The classification of life forms of plants is determined according to (Raunkiaer, 1934). The study of the methods of reproduction and distribution of adventive species on the territory of agricultural lands of Volyn' Polissya showed that the overwhelming majority of them (more than 90\%) reproduce with 
the help of seeds. Other species combine vegetative and seed propagation. Several species in the region reproduce only vegetatively. Of the species that multiply by seeds, most use multiple methods of spreading fruits and seeds. Autochory (self-spreading) and ballistochory (through the swaying of plants ) are observed most often, they do not require any additional external factors for their distribution. Anemochory (it is spread by the wind) and endozoochory (through the alimentary tract of animals or birds) are much less common. Thus, the presented adventive plant species are adapted quite well for distribution in new territories.

An analysis of the phytocenotic participation of non-native species in the structure of the flora of agricultural plots and in the adjacent territory showed that only a few species play a significant role in the formation of vegetation cover. So, when sowing row crops, these are species such as Echinochloa crusgalli L., Setaria glauca L. and S. viridis (L.) Beauv., Amaranthus retroflexus L., Fallopia convolvulus (L.) A. Love, Galinsoga parviflora Cav., G. canadensis (Rafin.) Blake. Activity in some cases is exhibited by Sinapis arvensis L. and Raphanus raphanistrum L. Papaver rhoeas L., Sonchus arvensis L., Centaurea cyanus L., Capsella bursapastoris (L.) Medik., Apera spica-venti (L.) Beauv., and Vicia villosa Roth are most often found in the groupings of broadcast-sown crops. Species such as Conyza canadensis L., Cichorium intybus L. and Phalacroloma anпuи $\mathrm{L}$. are distinguished by their phytocenotic participation on pastures and meadows with intensive grazing of animals, and on sandy and sandy loam soils equivalent participation is shown by Oenothera biennis L. and $O$. rubricaulis Klebahn.

It is very important to clarify the ways of entry and migration of adventive species to new territories to understand the modern processes of florogenesis. The main paths are the penetration of those species that are directly related to the technology of agricultural production: this is their introduction with insufficiently purified supplies of seeds and planting material, and with the addition of organic fertilizers. For example, Ambrosia artemisiifolia seeds are imported or spread through contaminated bird feed, soil (also in tire treads) and agricultural products from contaminated areas. Ambrosia seeds survive in soil for up to 40 years (Buters et al., 2015). However, the most probable ways of introducing non-native species are through their migration from adjacent territories. At the same time, the main centres of migration are weed grown areas of land and, especially, uncultivated abandoned fields, fallows, and other abandoned places. The migration flow of invasive species is significantly intensified when agricultural land is directly adjacent to communication routes, residential landscapes and urbanized territories with their infrastructure, and their species composition becomes more diverse.

In general, the territory in which agricultural production is carried out has been largely transformed by the anthropogenic ecological complexes or semi-natural ecological systems that have developed on it. Such territories currently occupy more than a third of the entire area in Volyn' Polissya. The extreme level of transformation is achieved in arable land occupied by row crops or broadcast-sown crops. There is a constant disturbance of the soil cover due to its processing cultivation. Areas with a disturbed substrate are the most amenable for the settlement of synanthropic species, including adventive ones. Unstable vegetation cover, which changes annually according to crop rotation patterns, cannot be a strong enough competitor to curb weed infestation. The situation is especially complicated by insufficient attention or neglect of weed control measures. The weed grown areas become a source of distribution of aboriginal and adventive synanthropic plant species to adjacent, including natural territories. Other authors also point out that, for example, land-use changes, anthropogenic changes in ecosystems and the development of transport networks have contributed to the successful spread of Solidago sp. over the past century to a large extent (Priede, 2008). In addition, the production and release of allelopathic compounds by the Solidago canadensis plant may be one of the mechanisms that explain the success of invasive weeds. The absence of a history of co-evolution has a detrimental effect on neighbouring plants in the range of introduction (Abhilasha et al., 2008).

A much better situation is observed in areas occupied by well-formed crops of perennial grasses, provided they are used as hayfields or for light grazing. In the first or second year of existence, the weediness of such crops approaches the same values as in areas of broadcast-sown crops, where it is mainly represented by annuals. In the future, as the projective cover of perennial herbaceous plants increases and a stable core of the vegetation cover is formed, weediness decreases sharply, primarily due to the loss of annual weeds. The reverse stage in the development of weeds begins with the liquefaction of the herbage of cultivated crops. At the same time, the phytocenotic role of perennial weeds is growing; they begin to occupy niches that were previously occupied by cultivated perennials. The thinning of crops of perennial grasses is significantly accelerated as a result of intensive grazing of cattle. First, there is a significant reduction in the projective cover of the cultivated grass stand, and then the trampling and compaction of the soil. In addition, the movement of animals during grazing promotes the spread of seeds or other weed diasporas. For the same reason, the dispersal of weeds, including non-native species, occurs in the meadowlands used for constant grazing throughout the growing season.

The transformer plants $S$. canadensis and $P h$. annuum not only change the abiotic conditions of habitats and displace native species of flora. They cause significant restructuring of plant communities in natural and semi-natural ecotopes. This is supported by data from other authors (Protopopova \& Shevera, 2014; Protopopova et al., 2015).

Thus, the analysis of the processes of flora adventitization on the territory of Volyn' Polissya allows us to single out several main complex factors that contribute to biological pollution by non-native plant species. We take into account the specifics of the physical-geographical and land use-economic conditions of the region and can agree with other authors that the main factors of flora adventization are agricultural production (Burda, 2001, 2006; Burda et al., 2013, 2017; Gerstnere et al., 2014; Buzhdyhan et al., 2016), urbanization (Makukh et al., 2015; Besarabchuk \& Volgin, 2018; Shavrina et al., 2018), and the feralization of introduced plant species (Protopopova et al., 2006; Pysek, 2008; Burda, 2013; Khaurdinova, 2014; Shevera et al., 2016).

Control over the spread of adventive species, for example, Ambrosia artemisiifolia, is still a serious problem for European countries (Cardarelli et al., 2018) and the potential for its further spread is quite high (Ortmans et al., 2017). Around 13.5 million people in Europe suffered from ragweed allergies, resulting in annual costs of $€ 7.4$ billion (Schaffner et al., 2020). Full control over Heracleum sosnowskyi can be achieved either by cutting the roots of plants up to 5 years old at a depth of $15 \mathrm{~cm}$ or by continuous (5 years long) herbicide spraying three times during the vegetative season, using a tank mixture of glyphosate and flazasulfuron (Klima \& Synowiec, 2016).

We take into account the current state of the species of adventive plants and the observed trends. Therefore, adventive plants can be placed according to the degree of naturalization in the following ascending order: ergasiophytes - ephemerophytes - colonophytes - epecophytes - agrioepecophytes and agriophytes. An analysis of the distribution of species by the degree of naturalization indicates a significant predominance of epecophytes, which are represented by more than $46.0 \%$ of the adventive species. These species are naturalized in various types of anthropogenically transformed ecotopes. The ergasiophytes are also abundant, accounting for $27.0 \%$. The significant share of the species of this group is a clear confirmation of the important role of the process of feralization of ornamental introduced species and cultivated plants in the adventization of the flora of the region. The total share of epecophytes and agro-epecophytes makes up the majority of the entire species composition of the fraction. This is evidence of the stability of their positions, as well as the presence on the territory of the region of considerable areas of disturbed and transformed ecotopes. The ephemerophytes are represented by approximately $6.0 \%$. The colonophytes are represented by 16 species. They are located more or less compactly and do not show a noticeable tendency to expand their growing area or appear at new sites. The smallest number of species is represented by agriophytes $3.8 \%$. The total share of agriophytes and agrio-epecophytes is about $15.0 \%$. These are species that have mastered mainly natural and semi-natural ecotopes. They are the ones that pose the greatest danger to the native flora.

The flora of the Volyn' Polissya contains a larger proportion of agriophytes and agrio-epecophytes than the adventive fraction of the flora of the entire Polissya of Ukraine ( $15.6 \%$ versus $12.0 \%$ ). At the same time, the adventive fraction of the studied region has fewer epecophytes compared to Eastern Polissya (46.0\% versus 59.0\%), ergasiophytes (27.2\% 
versus $36.0 \%$ ), and ephemerophytes (6.6 versus $11.2 \%$ ). An assessment of the dynamics of the species composition of the adventive fraction showed that over the past $30-50$ years, at least 80 species of flora new to Volyn' Polissya have appeared. These include: Equisetum ramosissimum, Oxybaphus nyctagineus, Amaranthus powelli, Lepidium campestris, Sisymbrium volgense, Poterium polygamum, Cerasus pumilla, Grindelia squarrosa, Rudbeckia laciniata, Carduus nutans, Bromus catharticus, Glyceria striata, Eragrostis suaveolens, Setaria verticillata, Hordeum murinum and others. The number of localities and the total population has been decreasing in the last 10-15 years for the following species: Matricaria recutita, Xanthium strumarium, Helianthus annuus, Solanum nigrum, Trifolium hybridum, Lepidium ruderale, Silene gallica, Thlaspi arvense, and Lamium album. This is confirmed by our observations and literature data. Some species of non-native plants have become quite rare. There are: Hyoscyamus niger, Datura stramonium, Althaea officinalis, and Agrostemma githago. Also, it was not possible to confirm the presence in the region of the following species: Xanthium spinosum, X. italicum, Fumaria schleicheri, Lepidium latifolium, Silene armeria, Anchusa officinalis, Cuscuta suaveolens, and Coronopus squamatus. Most likely they no longer grow in Volyn' Polissya.

The structure of the adventive fraction according to the time of appearance indicates that the greatest dynamics of the introduction and naturalization of species has been observed in the last 50-60 years. This is almost a third of the total species composition of the fraction. The ergasiophytes constitute a significant part of the adventive fraction (by the way of drift). Therefore, the modern dynamics of the adventitization of the regional flora can be largely explained by the fact that the range of cultivated introduced ornamental and floral-ornamental plants has greatly increased. The popularity of growing this type of plants among the local population is increasing. Further emergence of new wild introduced species can be predicted. This is a consequence of the greater availability of new planting and seed material against the background of the population ignoring phytosanitary measures.

Recommendations are not justified, in our opinion, for the introduction of individual ruderals into the culture, for example, for landscaping. These plants displace over time displace the native flora allelopathically and competitively. Ruderals create transformer biotopes, spontaneous phytocenoses, etc. We can also agree with a number of authors (Protopopova \& Shevera, 2014; Tkach et al., 2017, 2018), who believe that agricultural production is a powerful complex transformation factor for the environment as a whole, and natural flora in particular. Invasive alien plants are undoubtedly a growing concern not only in Ukraine but around the world. The ability to effectively manage them remains an urgent task. Climate change in recent decades has only exacerbated this problem.

\section{Conclusion}

The expansion of agricultural land over the past 50 years has led to an increase in the number of adventive species on the territory of Volyn' Polissya by more than $60 \%$. The increase in their number is associated with drainage reclamation, significant changes in the structure and forms of production of the agro-industrial complex in the region, climatic changes (aridization). More than $40 \%$ of the total species composition of the adventive flora of Volyn' Polissya is represented in the territory of drainage systems used for agricultural activities. The vast majority of species of the adventive flora growing on agricultural lands originate from arid and subarid regions of the planet. A significant potential hazard is represented by $S$. canadensis and Ph. annuum to phytocenoses. A. artemisiifolia and $H$. sosnowskyi may pose a serious threat to the natural phytodiversity and structure of agricultural landscapes in the region in the future. The analysis showed that the modern agroecosystems of Volyn' Polissya are characterized by instability and low ability to withstand non-native plant species. The ratio of archaeophytes and kenophytes is approximately the same, with a slight predominance of the former among all discovered non-native plant species. The spectrum of life forms of the identified invasive species is markedly dominated by annual herbaceous plants, or therophytes. A significant phytocenotic role in the composition of the groups of cultivated crops is shown only by a few species of the adventive flora, despite their wide distribution. When optimizing agricultural landscapes, it is advisable to carry out control and regulation not only of expansionary invasive species, this is especially important for preventing biological pollution, but also for species whose status is not yet determined. It is these species that quickly penetrate into agricultural landscapes and can easily be removed from ecosystems.

\section{References}

Abhilasha, D., Quintana, N., Vivanco, J., \& Joshi, J. (2008). Do allelopathic compounds in invasive Solidago canadensis restrain the native European flora? Journal of Ecology, 96, 993-1001.

Andriyenko, T. L. (1985). Antropogennyye izmeneniya rastitel'nosti Ukrainskogo Poles'ya [Anthropogenic changes in vegetation of Ukrainian Polissya]. Phytocenology of anthropogenic vegetation: Interuniversity scientific collection. Bashkir State University, Ufa. Pp. 15-29 (in Russian).

Artemenko, V. I., \& Beskrovny, A. K. (1972). Sel'skokhozyaystvennoye ispol'zovaniye osushennykh torfyano-bolotnykh pochv [Agricultural use of drained peat bog soils]. Urozhay, Kyiv (in Russian).

Baker, H. G. (1986). Patterns of plant invasion in North America. The ecology and biological invasions of North America and Hawaii. Springer, N.Y.

Baležentienė, L., Stankevičienė, A., \& Snieškienė, V. (2013). Heracleum sosnowskyi (Apiaceae) seed productivity and establishment in different habitats of Central Lithuania. Ekologija, 59(3), 123-133.

Besarabchuk, I., \& Volgin, S. (2018). Faktory poshyrennya Ambrosia artemisifolia L. (Asteraceae Dumort.) na terytoriyi m. Luts'ka (Volyns'ka oblast') [Factors of distribution of Ambrosia artemisifolia L. (Asteraceae Dumort.) in the city of Lutsk (Volyn' region)]. Visnyk of the Lviv University, Series Biology, 79, 53 60 (in Ukrainian).

Blinkova, O. I. (2017). Ekoloho-fitotsenotychna otsinka postmelioratyvnoyi dynamiky lisovoyi roslynnosti Volyns'koho Polissya [Ecological and phytocoenotical evaluation of postreclamative dynamics of forest vegetation of Volyn'ia]. Problems of Ecological Biotechnology, 1, 20-39 (in Ukrainian).

Burda, R. I. (2001). Otsinka ekolohichnoyi zahrozy zanosnykh roslyn v ahrolanshaftakh Ukrayiny [Assessment of alien plants ecological threat for the Ukrainian agricultural landscape]. Industrial Botany, 1, 16-21 (in Ukrainian).

Burda, R. I. (2006). Tendentsiyi zmin riznomanitnosti fitobioty v sil's'kohospodars'kykh landshaftakh Rivnynnoyi Ukrayiny [Trends in changes in phytobiota diversity in agricultural landscapes of Plain Ukraine]. Scientific Bulletin of the National Agrarian University, 93, 1-15 (in Ukrainian).

Burda, R. I. (2013). Introduktsiya rasteniy: Okul'turivaniye i naturalizatsiya [Introduction of plants: Domestication and naturalization]. Industrial Botany, 13, 3-15 (in Russian).

Burda, R. I. (2017). Aktual'ni nomenklaturni i taksonomichni zminy vydovoho skladu pol'ovykh buryaniv Ukrayiny [Current nomenclature and taxonomic changes in the species composition of field weeds in Ukraine]. Agroecological Journal, 2, 182-187 (in Ukrainian).

Burda, R. I., Golivets, M. A., \& Petrovych, O. Z. (2015). Alien species in the flora of the nature reserve fund of the flatland part of Ukraine. Russian Journal of Biological Invasions, 6(1), 6-20.

Burda, R. I., Pashkevych, N. A., Blinkova, O. I., Shupova, T. V., Stukalyuk, S. V., Ivanenko, O. M., \& Bilushenko, A. A. (2018). Adaptyvna stratehiya populyatsiy adventyvnykh vydiv [Adaptive strategy of populations of adventive species]. Naukova Dumka, Kyiv (in Ukrainian).

Burda, R. I., Vlasova, N. L., Kolomiez, G. V., Mirovska, N. V., \& Tkatch, E. D. (2004). Comparative assessment of diversity of phytobiota in agricultural landscapes of Ukraine, based on hemeroby. Ukrainian Botanical Journal, 61(3), 37-46.

Buters, J., Alberternst, B., Nawrath, S., Wimmer, M., Traidl-Hoffmann, C., Starfinger, U., Behrendt, H., Schmidt-Weber, C., \& Bergmann, K. C. (2015). Ambrosia artemisiifolia (ragweed) in Germany - current presence, allergological relevance and containment procedures. Allergo Journal International, 24, 108-120.

Buzhdyhan, O. Y., Bahley, O. V., \& Rudenko, S. S. (2016). Anthropogenic transformation of phytocenoses of meadow ecosystems under the influence of pastoral economic activity. Bulletin of Agricultural Science, 11, 66-71.

Cardarelli, E., Musacchio, A., Montagnani, C., Bogliani, G., Citterio, S., \& Gentili, R. (2018). Ambrosia artemisiifolia control in agricultural areas: Effect of grassland seeding and herbivory by the exotic leaf beetle Ophraella communa. NeoBiota, $38,1-22$.

Dolzhenchuk, V. I., \& Krupko, H. D. (2015). Monitoring processes of degradation and desertification in Rivne region. Agroecological Journal, 10(1), 69-75.

Dubyna, D. V., Iemelianova, S. M., Dvoretzkiy, T. V., Dziuba, T. P., \& Tymoshenko, P. A. (2019). Adventization of coenofloras of the classes of pioneer vegetation in Ukraine. Ukrainian Botanical Journal, 76(6), 499-510.

Gerstner, K., Dormann, C. F., Stein, A., Manceur, A. M., \& Seppelt, R. (2014). Effects of land use on plant diversity - a global meta-analysis. Joumal of Applied Ecology, 51(6), 1690-1700.

Hadjikyriakou, G., \& Hadjisterkotis, E. (2002). The adventives plants of Cyprus with new records of invasive species. Zeitschrift für Jagdwissenschaft, 48, 59-71. 
Jager, E. (1988). Möglichkeiten der Prognose synanthroper Pflanzen ausbreilimgen. Flora, 180, 101-131.

Kauffer, C., Pešek, P., \& Richardson, D. (2013). Integrative invasion science: Model systems, multi-site studies, focused meta-analysis and invasion syndromes. New Phytologist, 200, 615-633

Khaurdinova, H. O. (2014). Features of vegetation change in artificial forest plantations. Forestry and Horticulture, 4, 12.

Khomyak, I. V. (2018). Features of anthropogenic impact on the natural dynamics of ecosystems of Ukrainian Polissya. Environmental Sciences, 1(20), 69-73.

Klima, K., \& Synowiec, A. (2016). Field emergence and the long-term efficacy of control of Heracleum sosnowskyi plants of different ages in Southern Poland. Weed Research, 56(5), 377-385.

Kochik, G. M. (2012). Osoblyvosti formuvannya zabur'yanenosti gruntu i posiviv u rehioni Polissya Ukrayiny [Peculiarities of soil and weed formation in the Polissya region of Ukraine]. Agroindustrial Production of Polissya, 5, 30-35 (in Ukrainian).

Kornas, A. (1968). Geographical-historical classification of synanthropic plants. Materialy Zakladu Fitosocjologii Stosowanej Uniwersytetu Warszawskiego, 25, 33-41.

Korotun, I. M., \& Korotun, L. K. (1996). Heohrafiya Rivnens'koyi oblasti [Geography of Rivne region]. Institute of Advanced Training of Pedagogical Staff, Rivne (in Ukrainian).

Kozlovsky, B. I. (2005). Rekul'tyvatsiya osushenykh zemel' zakhidnykh oblastey Ukrayiny [Reclamation of drained lands of western regions of Ukraine]. Euroworld, Lviv (in Ukrainian).

Kuzemko, A. (2013). Anthropogenic transformation of the grassland vegetation of forest and forest-steppe zones of Ukraine in temporal and spatial scales. 22nd EVS International Workshop: Book of Abstract (Rome, 9-11 Apr. 2013). University of Rome, Botanic Garden, Rome. P. 58.

Lonsdale, W. M. (1999). Global patterns of plant invasions and the concept of invisibility. Ecology, 80(5), 1522-1536.

Makukh, Y. P., Remeniuk, S. O., \& Moshkivska, S. V. (2015). Borshchivnyk Sosnovs'koho $\mathrm{v}$ posivakh yachmenyu [Heracleum sosnowskyi in barley crops]. Quarantine and Plant Protection, 10, 6-13 (in Ukrainian).

Oitsius, L. V. (2014). Impact of the adventives species plants on biodiversity of the Volyn' Polissya. Bulletin of NUWEE, Agricultural Sciences, 62, 115-122 (in Ukrainian).

Ortmans, W., Mahy, G., \& Monty, A. (2017). Northern range edge equilibrium of Ambrosia artemisiifolia L. not achieved in Westem Europe. Biotechnology, Agronomy, Society and Environment, 21(1), 12-21.

Priede, A. (2008). Invasive non-native Solidago species in Latvia: Expansion history and current distribution. Proceedings of the Latvian Academy of Sciences, Section B, Natural, Exact, and Applied Sciences, 62(1), 78-83.

Protopopova, V. V., \& Shevera, M. V. (2012). Phytoinvasions. II. Analysis of the main classifications, schemes and models. Industrial Botany, 12, 88-95.

Protopopova, V. V., \& Shevera, M. V. (2014). Ergasiophytes of the Ukrainian flora. Biodiversity Research and Conservation, 35(1), 31-46.

Protopopova, V. V., Mosyakin, S. L., \& Shevera, M. V. (2003). Vplyv adventyvnykh vydiv roslyn na fitobiotu Ukrayiny [Influence of adventives plant species on the phytobiota of Ukraine]. In: Dudkin, O. B. (Ed.). Assessment and directions of reducing threats to biodiversity of Ukraine. Himgest, Kyiv (in Ukrainian).

Protopopova, V., Shevera, M., Orlov, O. O., \& Panchenko, S. M. (2015). The transformer species of the Ukrainian Polissya. Biodiversity Research and Conservation, 39(1), 7-18.

Protopopova, V. V. (1991). Sinantropnaya flora Ukrainy i puti yeye razvitiya [Synanthropic flora of Ukraine and ways of its development]. Naukova Dumka, Kyiv (in Russian).
Pysek, P., Jarosík, V., Müllerová, J., Pergl, J., \& Wild, J. (2008). Comparing the rate of invasion by Heracleum mantegazzianum at continental, regional, and local scales. Diversity and Distributions, 14(2), 355-363.

Rabotnov, T. A. (1983). Fitotsenologiya [Phytocenology]. MSU Publishing House, Moscow (in Russian).

Raunkiaer, C. (1934). The life forms of plants and statistical plant geography. Oxford University Press, London.

Richardson, D. M., Pysek, P., Rejmanek, M., Barbour, M. G., Panetta, F. D., \& West, C. J. (2000). Naturalization and invasion of alien plants: Concepts and definitions. Diversity and Distribution, 6, 93-107.

Sabirova, N. D., Sabirov, R. N., \& Lozhnikova, O. O. (2019). The invasive plant species in the flora of Sakhalin. Geodynamical Processes and Natural Hazards: 2019 III National scientific conference with foreign participants. YuzhnoSakhalinsk, Russian Federation. IOP Conference Series: Earth and Environmental Science, 324, 012036.

Schaffner, U., Steinbach, S., Sun, Y., Skjøth, C., de Weger, L., Lommen, S., Augustinus, B., Bonini, M., Karrer, G., Šikoparija, B., Thibaudon, M., \& MüllerSchärer, H. (2020). Biological weed control to relieve millions from Ambrosia allergies in Europe. Nature Communications, 11, 1745.

Serebryakov, I. G. (1962). Ekologicheskaya morfologiya rasteniy [Ecological morphology of plants]. Higher School, Moscow (in Russian).

Shavrina, V. I., Tkach, E. D., \& Mykolayko, V. P. (2018). Synantropic flora in phytocoenoses of ecological network (the case of Vinnytsia region, Ukraine). Ukrainian Journal of Ecology, 8(1), 118-123.

Shevchuk, O. M. (2013). Typolohichna struktura florokompleksiv Pasovyshchnykh ekosystem pivdennoho skhodu Ukrayiny [Typological structure of floral complexes of pasture ecosystems in the south-east of Ukraine]. Industrial Botany, 13, 35- 42 (in Ukrainian).

Shevera, M., Protopopova, V., Didukh, Y., Kozak, O., Chorney, I., Budzhak, V., \& Tokaryuk, A. (2016). Reaction on invasive species on climatic changes. XI International Conference Advances in research on the flora and vegetation of the CarpatoPannonian region. Budapest, Hungary. Pp. 106-107.

Sobko, Z. Z., \& Voznyuk, N. M. (2018). Monitorynh vyrobnytstva sil's'kohospodars'kykh kul'tur na terytoriyi Rivnens'koyi oblasti [Monitoring of manufacture of agricultural crops on the territory of Rivne region]. Taurian Scientific Bulletin, $100(2), 68-75$ (in Ukrainian).

Tkach, E. D., Sherstoboeva, O. V., \& Shavrina, V. I. (2018). Fitobiotychne riznomanittya pryrodnykh fitotsenoziv ahrolandshaftiv Ukrayiny [Phytobiotic diversity of natural phytocenoses of agrolandscapes of Ukraine: monograph]. Naukova Dumka, Kyiv (in Ukrainian).

Tkach, E. D., Sherstoboieva, O. V., Kryzhanivskyi, A. B., Starodub, V. I., Shavrina, V. I., \& Lobova, O. V. (2017). Naukovo-metodychni osnovy otsinky ahrofitotsenoziv v umovakh zmin klimatu [Scientific and methodological bases of estimation of agrophytocenoses in conditions of climate change]. Naukova Dumka, Kyiv (in Ukrainian).

Volodymyrets, V. A., \& Shklyaruk, L. V. (2006). Osoblyvosti vydovoho skladu adventyvnoyi flory Volyns'koho Polissya [Peculiarities of the species composition of the adventitious flora of Volyn' Polissya]. Scientific Bulletin of Lesya Ukrainka Volyn' State University, 1, 22-26 (in Ukrainian).

Ward, S. G., \& Amatangelo, K. L. (2018). Suburban gardening in Rochester, New York: Exotic plant preference and risk of invasion. Landscape and Urban Planning, 180, 161-165.

Witt, A., Beale, T., \& van Wilgen, B. W. (2018). An assessment of the distribution and potential ecological impacts of invasive alien plant species in eastern Africa. Transactions of the Royal Society of South Africa, 73(3), 217-236.

Yakubenko, B. Y., \& Churilov, A. M. (2019). Biomorphological structure of restored vegetation cover of abandoned lands of the Forest-Steppe of Ukraine. Ukrainian Journal of Forest and Wood Science, 10(3), 79-85. 